\title{
Ichthyofauna of the Mata de Itamacaoca, an urban protected area from the upper Munim River basin, Northern Brazilian Cerrado
}

\author{
Elioenai da Silva Oliveira $^{1,2}$, Erick Cristofore Guimarães ${ }^{2,3} \mathbb{\complement}$, Pâmella Silva de Brito ${ }^{2,3} \mathbb{C}^{\circ}$ Lucas de Oliveira Vieira ${ }^{2}$, \\ Rafael Ferreira de Oliveira ${ }^{2}$, Diego Sousa Campos $^{2,5}$, Axel Makay Kat $^{4}{ }^{4}$, Josie South $^{6,7}$, Jorge Luiz Silva Nunes $^{1,3,8}$ \& \\ Felipe Polivanov Ottoni ${ }^{1,2,3,5 * \mathbb{C}}$ \\ ${ }^{1}$ Universidade Federal do Maranhão, Programa de Pós-Graduação em Biodiversidade e Conservação, Av. dos \\ Portugueses, 1966, Cidade Universitária Dom Delgado, 65080-805, São Luís, MA, Brasil. \\ ${ }^{2}$ Universidade Federal do Maranhão, Laboratório de Sistemática e Ecologia de Organismos Aquáticos, Centro de \\ Ciências Agrárias e Ambientais, Campus Chapadinha, BR-222, KM 04, Boa Vista, 65500-000, Chapadinha, \\ MA, Brasil. \\ ${ }^{3}$ Universidade Federal do Maranhão, Programa de Pós-Graduação em Biodiversidade e Biotecnologia da \\ Amazônia Legal, Av. dos Portugueses, 1966, Cidade Universitária Dom Delgado, 65080-805, São Luís, MA, \\ Brasil. \\ ${ }^{4}$ Universidade Federal do Rio de Janeiro, Laboratório de Sistemática e Evolução de Peixes Teleósteos, \\ Departamento de Zoologia, Instituto de Biologia, Cidade Universitária, 21941- 599, Rio de Janeiro, RJ, Brasil. \\ ${ }^{5}$ Universidade Federal do Maranhão, Programa de Pós-Graduação em Ciências Ambientais, Centro de Ciências \\ Agrárias e Ambientais, Campus Chapadinha, BR-222, KM 04, Boa Vista, 65500-000, Chapadinha, MA, Brasil. \\ ${ }^{6}$ Centre for Invasion Biology, South African Institute for Aquatic Biodiversity, Makhanda, 6140, South Africa. \\ ${ }^{7}$ Department of Science and Innovation/National Research Foundation, Research Chair in Inland Fisheries and \\ Freshwater Ecology, South African Institute for Aquatic Biodiversity, Makhanda, South Africa. \\ ${ }^{8}$ Universidade Federal do Maranhão, Departamento de Oceanografia a e Limnologia, Laboratório de \\ Organismos Aquáticos, São Luís, MA, Brasil. \\ *Corresponding author: Felipe Polivanov Ottoni, e-mail: fpottoni@gmail.com
}

OLIVEIRA, E.S., GUIMARÃES, E.C., BRITO, P.S., VIEIRA, L.O., OLIVEIRA, R.F., CAMPOS, D.S., KATZ, A.M., SOUTH, J., NUNES, J.L.S., OTTONI, F.P. Ichthyofauna of the Mata de Itamacaoca, an urban protected area from the upper Munim River basin, Northern Brazilian Cerrado. Biota Neotropica 20(4): e20201116. https://doi.org/10.1590/1676-0611-BN-2020-1116

\begin{abstract}
The Munim River basin is one of the main river drainages of the Hydrological unit Maranhão, but there are few published studies which focus on ichthyological surveys and taxonomic work within this basin. The present study aims to provide a fish species inventory of the Mata da Itamacaoca, one of the few urban protected areas from the upper Munim River basin, comparing the ichthyofauna with other lists by conducted at the upper Munim River basin. A total of 42 collection expeditions were conducted, the sampling was conducted at five collecting sites distributed within the boundaries of Mata de Itamacaoca, upper Munim River basin. Diversity indices were calculated and generalised linear models (GLMs) were employed to assess differences in species richness, diversity and evenness depending on season and location in relation to the reservoir dam wall. In order to visualize fish community differences, non-metric multidimensional scaling (nMDS) and a one-way PERMANOVA was used to understand whether factors of site, season and location to the dam wall had an effect on fish community compositions. A total of six orders, 13 families, and 23 fish species were found, and the order with the highest species richness, considering all reaches, was Characiformes followed by Cichliformes. The most abundant species was Nannostomus beckfordi, while Pimelodella parnahybae and Hoplerythrinus unitaeniatus were the rarer species sampled. There were no alien invasive species collected within the study area. Species richness was significantly higher below the dam wall, but there were no other significant differences in diversity indices with regards to season or location. Fish community composition was significantly different above and below the dam wall and was significantly affected by sampling site. Season did not have an effect on fish community. This study corroborates other studies conducted in the Unidade Hidrológica Maranhão sensu Hubbert and Renno (2006), that the ichthyofaunal composition and taxonomy of species within this region face major data deficits, anthropogenic impacts, this study may be a baseline for comparing similar environments throughout the region.
\end{abstract}

Keywords: Biodiversity, Conservation, fish inventory, Maranhão, Neotropical, Species richness. 


\title{
Ictiofauna da Mata de Itamacaoca, uma area de proteção urbana da bacia do alto Rio Munim, Cerrado norte brasileiro
}

\begin{abstract}
Resumo: A bacia do rio Munim é uma das principais drenagens da unidade Hidrológica do Maranhão, mas existem poucos estudos publicados que enfoquem levantamentos ictiológicos e trabalhos taxonômicos dentro desta bacia. $\mathrm{O}$ presente estudo tem como objetivo fornecer um inventário de espécies de peixes da Mata da Itamacaoca, uma das poucas áreas protegidas urbanas da bacia do alto rio Munim, comparando a ictiofauna com outras listas realizadas na bacia do alto rio Munim. Foram realizadas 42 expedições de coleta, a amostragem foi conduzida em cinco locais de coleta distribuídos dentro dos limites da Mata de Itamacaoca, bacia do alto rio Munim. Índices de diversidade foram calculados e modelos lineares generalizados (GLMs) foram empregados para avaliar diferenças na riqueza de espécies, diversidade e equitabilidade dependendo da estação e localização em relação à parede da barragem do reservatório. A fim de visualizar as diferenças da comunidade de peixes, escalonamento multidimensional não métrico (nMDS) e um PERMANOVA unilateral foi usado para entender se os fatores de local, estação e localização da parede da barragem afetavam a composição da comunidade de peixes. Um total de seis ordens, 13 famílias e 23 espécies de peixes foram encontradas, sendo que a ordem com maior riqueza de espécies, considerando todos os trechos, foi Characiformes seguida por Cichliformes. A espécie mais abundante foi Nannostomus beckfordi, enquanto Pimelodella parnahybae e Hoplerythrinus unitaeniatus foram as espécies mais raras amostradas. Não houve espécies exóticas invasoras coletadas na área de estudo. A riqueza de espécies foi significativamente maior abaixo da parede da barragem, mas não houve outras diferenças significativas nos índices de diversidade em relação à estação do ano ou localização. A composição da comunidade de peixes foi significativamente diferente acima e abaixo da parede da barragem, e foi significativamente afetada pelo local de amostragem. A estação do ano não afetou a comunidade de peixes. Este estudo corrobora outros estudos realizados na Unidade Hidrológica Maranhão sensu Hubbert and Renno (2006), que a composição ictiofaunística e taxonomia das espécies desta região enfrentam grandes déficits de dados. Impactos antropogênicos, este estudo pode ser uma linha de base para comparar ambientes semelhantes em toda a região.
\end{abstract}

Palavras-chave: Biodiversidade, Conservação, Inventário de peixes, Neotropical, Riqueza de espécies.

\section{Introduction}

The Neotropical freshwater ichthyofauna is the most species-rich of the world, comprising more than 6,000 described species, with estimates of over 9,000 species (Reis et al. 2016, Birindelli \& Sidlauskas 2018, Castro \& Polaz 2020). Within this huge species assemblage, most (about $70 \%$ ) are small-sized fishes, with adults around $15 \mathrm{~cm}$ or less standard length (SL), which can inhabit a variety of aquatic environments, such as streams, small and large rivers, lagoons, pools, temporary pools, swamps, amongst others (Reis et al. 2003, Castro \& Polaz 2020). Literature concerning the diversity and evolution of the Neotropical ichthyofauna has improved in recent years; however, studies are still few and underestimate their real biodiversity (Buckup et al. 2007, Reis et al. 2016, Birindelli \& Sidlauskas 2018, Malabarba \& Malabarba 2020). In addition to the lack of taxonomic and ecological knowledge, the rapid loss and degradation of natural environments as a result of anthropogenic drivers (i.e. invasive species, climate change, abstraction, pollution etc) has affected many fish species (Agostinho et al. 2008, Nogueira et al. 2010, Azevedo-Santos et al. 2019, Castro \& Polaz 2020). Fish species which are particularly at risk are either charismatic megafauna or small sized fish species, the latter of which unfortunately receive rather less conservation attention (He et al. 2019, Castro \& Polaz 2020).

Due to the alarming rate of biodiversity loss, combined with multiple and interacting anthropogenic stressors, freshwater ecosystems are facing a "biodiversity crisis" (Darwall et al. 2018, Harrison et al. 2018). In the last two decades, the rate of species extinctions worldwide has been much higher than natural extinction rates, with the subsequent extinction of thousands of species and loss populations, several of them still unknown to the science.
This is of great concern within freshwater environments as the biotic communities represent around $6 \%$ of currently described species and yet are vastly understudied commensurate to the species diversity and ecosystem services that they represent (Dudgeon et al. 2006, Lynch et al. 2020). The mis-match in data availability and research output compared to intrinsic value is notable in Brazilian freshwater systems, whereupon species are threatened before they even are described and their ecology characterised (Wilson 1985, 1992, Brooks et al. 2002, Olson et al. 2002, Singh 2002, Brook et al. 2006, Laurance 2007, Wheeler 2008, Costa et al. 2012, Kalinkat et al. 2017, Azevedo-Santos et al. 2019).

Freshwater environments and the biota within are more vulnerable to global change than marine and terrestrial ecosystems, as such they warrant the need for urgent and special attention regarding diversity estimations and conservation actions (Arthington et al. 2016, Darwall et al. 2018, Harrison et al. 2018, Azevedo-Santos et al. 2019, Castro \& Polaz 2020). Unfortunately, designation of protected areas combined with current conservation policies, especially in Brazil, have limited efficacy in protecting freshwater biodiversity (Azevedo-Santos et al. 2019, Castro \& Polaz 2020). Due to the continued high rate of habitat destruction, the identification of new species and comprehensive compilations of regional inventories as well as improving the taxonomic resolution of under-studied and taxonomically confusing is a research priority. It is imperative that this occurs before these species and populations are extinct, so that appropriate interventions can be actioned, especially in areas of high risk of anthropogenically driven change (Brook et al. 2006, Laurence 2007, Wheeler 2008, Costa et al. 2012, Pimm et al. 2014, Darwall et al. 2018, Oliveira-Silva et al. 2018, Harrison et al. 2018, Frota et al. 2019). 
The Munim River basin $(\sim 16.000 \mathrm{~km} 2)$ is a coastal river basin located at the northeastern portion of the State of Maranhão (Ribeiro et al. 2014). It represents one of the main river drainages of the Hydrological unit Maranhão sensu Hubbert and Renno (2006) (Hereafter Mrn). This eastern portion of the Hydrological unit has conspicuously few published fish surveys and ichthyological taxonomic studies. Ribeiro et al. (2014) published a study on an artisanal fishing technique (known as Moita) conducted at the upper Munim River basin, listing 20 fish species, predominantly middle to large-sized species. Matavelli et al. (2015) conducted an inventory of fishes associated with tadpole community in lentic and lotic environments in northeastern Maranhão (some of the sampled areas belonging to the lower Munim River basin) listing 13 fish species. Guimarães et al. (2018a,b) described two new species of Characidae occurring at the upper Munim River basin; and Nunes et al. (2019) carried out a work on length-weight relationship of 15 species from the upper Munim River basin. This gap in knowledge, specifically relating to fish taxonomy and species assemblages is a shared trait throughout the Munim River Basin as well as other river drainages and basins from Mrn (Piorski, 2010, Guimarães et al. 2018a). Therein there is a massive lack of information related to the taxonomy and systematics of the species and groups, species composition, geographical distribution and biogeography of the ichthyofauna from this region.

The fluvial channels in the State Maranhão are constantly threatened by degradation. This includes: removal of riparian forests; pollution and contamination of rivers; occurrences of erosion processes intensified by human activities; and abstraction and fragmentation of watercourses. The Munim River basin is no exception to this trend (Ribeiro et al. 2006, Silva et al. 2008, Lima et al. 2009), and there is a high likelihood that this will significantly impact the regional biodiversity (Pelice et al. 2017).
Pervasive and damaging stressor effects upon a data deficit system means that subjects such as fish biodiversity and taxonomy within the Mrn should be urgently addressed in order to combat further losses within the region.

The present study aims to provide a fish species inventory of the Mata da Itamacaoca and compare the species listed by our survey with the species listed by the other published works conducted at the upper Munim River basin. The study area is an urban protected area from the upper Munim River basin, Northern Brazilian Cerrado, a biome considered as one of the world biodiversity hotspots according to Myers et al. (2000). This study is especially important, being considered a baseline for the region, because it was conducted within an urban protection area, which is more exposed to human impacts than other protected areas. In addition, due to fact the Mata de Itamacaoca is an urban protected area, we believe that it has an ichthyofauna representation closer to the original of the region than the other degraded areas. This thus allowed for us to estimate the ichthyofauna diversity for the upper Munim River basin, especially regarding the small-sized, rare, and more ecologically demanding species. We also assessed fish diversity with regards to season and position above or below the reservoir in order to assess for possible effects of fragmentation.

\section{Materials and Methods}

This study was conducted in the Mata de Itamacaoca, an urban protected area belonging to CAEMA (Companhia de Saneamento Ambiental do Maranhão). It is located within the Municipality of Chapadinha, State of Maranhão (2425'47" S, $58^{\circ} 44^{\prime} 05^{\prime} \mathrm{W}$ ), and is approximately 90 meters above sea level. The predominant biome in the region is the Brazilian Cerrado (Figure 1).

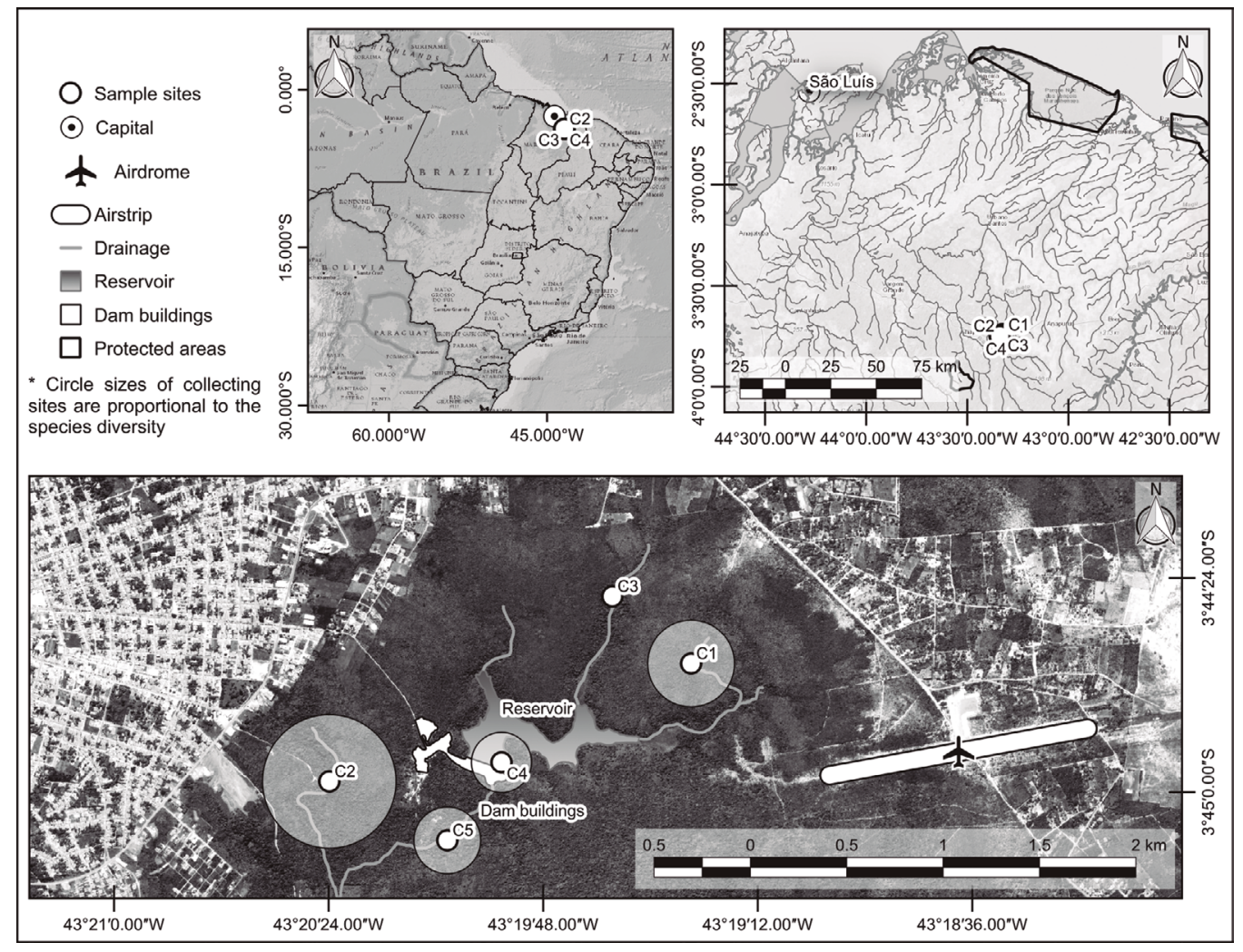

Figure 1. Map of the studied area. Collecting sites (C1-C5) listed in Table 1. 
The study area covers about 460 hectares consisting of a mosaic of plant formations including, along with the watercourses, riparian and gallery forests, as well as some stream springs; and formation of closed forest, with trees reaching more than 10 meters in height. The protected area was created to maintain water supply to the city, thus the need to preserve the integrity of vegetation around the springs, water bodies and reservoir (Silva et al. 2008). It is also important to emphasize that this area has been recognized as an Area of Relevant Ecological Interest for the conservation of fauna and flora by the Decreto Municipal No 05/2018.
The collection of samples was conducted at five sample sites (C1-C5) distributed within the boundaries of Mata de Itamacaoca, upper Munim River basin, comprising springs, streams, pools, and a reservoir (Table 1, Figures 1 and 2). A total of 42 collection expeditions were conducted. The collections occurred from August 2014 to February 2020, during both dry and wet seasons. All the collection expeditions were conducted during daylight, except for a one off night collection expedition conducted in October 2019 at $\mathrm{C} 4$.

Table 1. Samples localities at the Mata de Itamacaoca, upper Munim River basin, State of Maranhão, Brazil.

\begin{tabular}{|c|c|c|c|c|c|}
\hline Collecting site & Coordinates & Altitude (meters) & water temperature $\left({ }^{\circ} \mathrm{C}\right)$ & water ph & Remarks \\
\hline $\mathrm{C} 1$ & $\begin{array}{l}3^{\circ} 44^{\prime} 45.20^{\prime \prime S} \\
43^{\circ} 19^{\prime} 15.10^{\prime \prime} \mathrm{W}\end{array}$ & $\sim 80$ & $\sim 28.1$ & $\sim 6.2$ & $\begin{array}{l}\text { Stream near spring, with gallery and riparian } \\
\text { forest, at Mata de Itamacaoca, Municipality of } \\
\text { Chapadinha, State of Maranhão. } \\
\text { Obs.: collections on this site were conducted } \\
\text { through about } 200 \text { meters along the water course. }\end{array}$ \\
\hline $\mathrm{C} 2$ & $\begin{array}{l}3^{\circ} 44^{\prime} 58.24 " \mathrm{~S} \\
43^{\circ} 20^{\prime} 23.91^{\prime \prime} \mathrm{W}\end{array}$ & $\sim 90$ & $\sim 26.2$ & $\sim 6.6$ & $\begin{array}{c}\text { Stream in the locality Repouso do Guerreiro, } \\
\text { at Mata de Itamacaoca, Municipality of } \\
\text { Chapadinha, State of Maranhão. }\end{array}$ \\
\hline $\mathrm{C} 3$ & $\begin{array}{l}3^{\circ} 44 ' 27.1 ” \mathrm{~S} \\
43^{\circ} 19^{\prime} 36.4 ’ \mathrm{~W}\end{array}$ & $\sim 80$ & $\sim 26.8$ & $\sim 6.4$ & $\begin{array}{l}\text { Stream near spring, with gallery and riparian } \\
\text { forest, at Mata de Itamacaoca, Municipality of } \\
\text { Chapadinha, State of Maranhão. }\end{array}$ \\
\hline $\mathrm{C} 4$ & $\begin{array}{l}3^{\circ} 44^{\prime} 55.16^{\prime \prime} \mathrm{S} \\
43^{\circ} 19^{\prime} 57.10^{\prime \prime} \mathrm{W}\end{array}$ & $\sim 80$ & $\sim 30.7$ & $\sim 6.6$ & $\begin{array}{c}\text { Itamacaoca dam, Municipality of Chapadinha, } \\
\text { State of Maranhão. }\end{array}$ \\
\hline
\end{tabular}

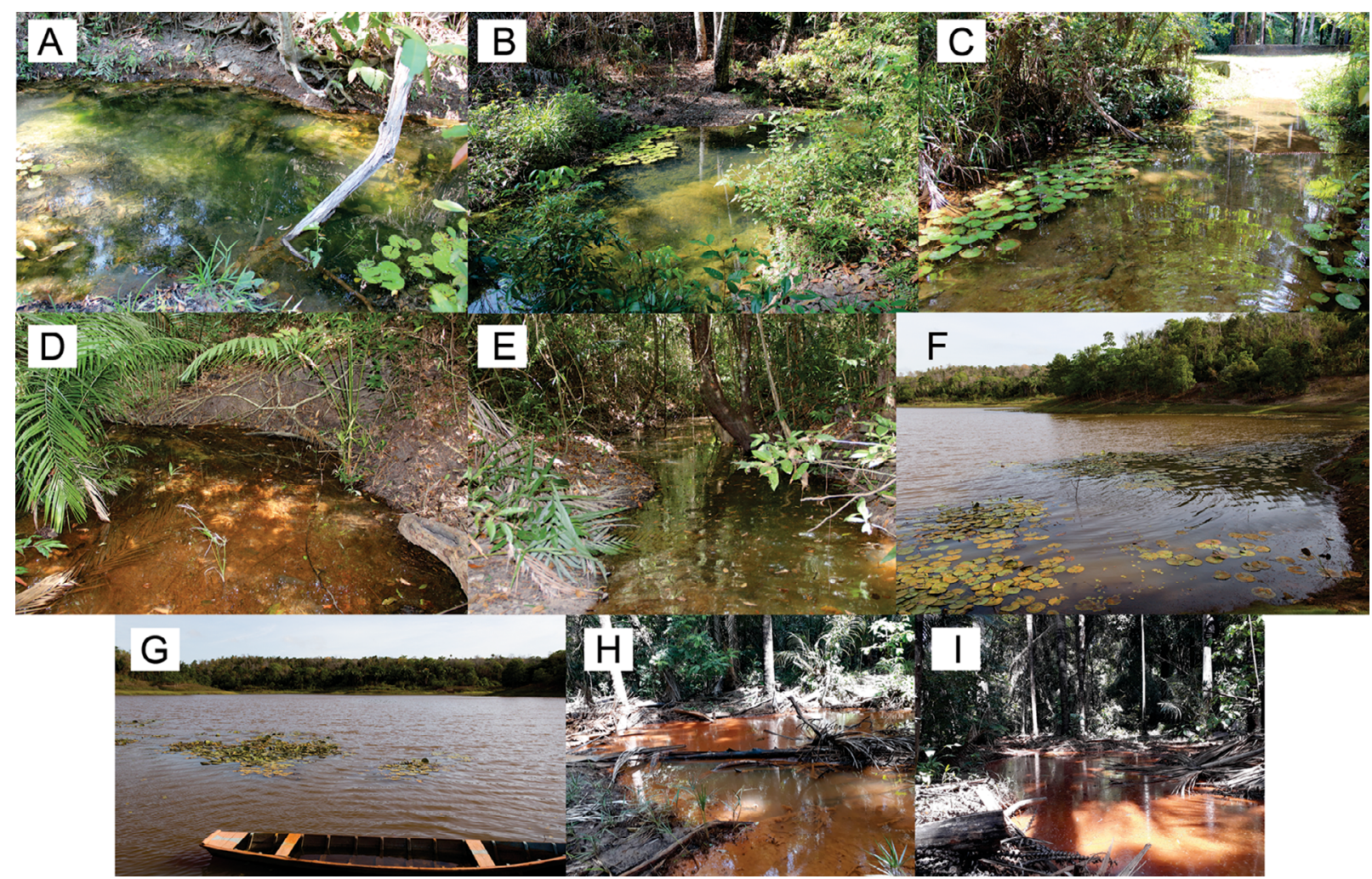

Figure 2. Collecting sites (C1-C5) listed in table 1. A and B - C1, C - C2, D and E - C3, F and G - C4, and H and I - C5. Photographed by Felipe Ottoni. 
Fishes were collected using manual trail-net $(2 \mathrm{~m}$ long $\times 1.8 \mathrm{~m}$ high; mesh size, $2 \mathrm{~mm}$ ), cast nets ( $2 \mathrm{~m}$ height, mesh size $15 \mathrm{~mm})$, gillnets of various mesh sizes $(15,20,25,30,35,40,45,50,60,70,80,100 \mathrm{~mm})$, and dip nets (mesh size 5 and $10 \mathrm{~mm}$ ). We tried to collect fishes using traps, such as "fish trap", but we were not successful. The ichthyological material obtained in the samples was euthanized in a buffered solution of ethyl-3-amino-benzoate-methanesulfonate (MS-222) at a concentration of $250 \mathrm{mg} / 1$ until completely ceasing opercular movements, according to animal welfare laws and guidelines (Close et al. 1996, 1997, Leary et al. 2013). Specimens selected for morphological analysis were fixed in formalin and left for 15 days, after which they were preserved in $70 \%$ ethanol. Molecular data also obtained from specimens, and preserved in absolute ethanol. Sorting and identification of specimens were carried out at the Laboratório de Sistemática e Ecologia de Organismos Aquáticos of the Universidade Federal do Maranhão using specialized bibliography for each taxonomic group and consulting experts. The ichthyological material is deposited in the Coleção Ictiológica do Centro de Ciências Agrárias e Ambientais of the Universidade Federal do Maranhão (CICCAA). A list of all the examined material is presented in Appendix 1. The taxonomic classification, the names of species considered as valid, authors and years of species descriptions, and geographic distribution, were based on the compilations proposed by Fricke et al. (2020a,b), where the authors gather all the most recent classifications for each group of fish.

In order to assess whether this baseline fish community assessment differed between season and location above or below the dam wall, diversity indices were calculated for each discrete sampling events per year. Whereupon, sampling in the dry season above the dam wall was $n=27$, rainy season above the dam wall $n=24$, dry season below the dam $\mathrm{n}=5$ and rainy season below the dam wall was $\mathrm{n}=7$.

As the data was unbalanced, a generalised linear model (GLM) was used to determine whether season (dry or rainy) and location with regards to the dam wall (above or below), including an interaction term, affected the species richness (Sprich).

Shannon-Weiner Index of Diversity (Shannon 1948) was calculated for each sampling date at site, season and locality above and below the dam using the package 'vegan' version 2.5-5 (Oksanen et al. 2019). This index describes the entropy of a given community:

$$
(H)=\sum_{i=1}^{s} p_{i} \ln p_{i}
$$

Where $\mathrm{H}$ is the Shannon diversity index, which has no bounded upper value, $\mathrm{S}$ is the total number of species in the community, $\mathrm{P}_{\mathrm{i}}$ is the proportion of S made up of the $i$ th species. Shannon's evenness (eqn 2) was calculated from the results of eqn 1 :

$$
E_{H}=H / H_{\max }=\ln S
$$

Where $E_{H}$ is Shannon's evenness, $H$ is Shannon's diversity index, and $\mathrm{H}_{\max }$ is the natural log of total species detected in the basin. $\mathrm{E}_{\mathrm{H}}$ is bounded between zero and one where one represents complete evenness. In some cases the $\mathrm{E}_{\mathrm{H}}$ could not be calculated due to zeros in the dataset. Separate GLMs were completed on the $\mathrm{H}$ and $\mathrm{E}_{\mathrm{H}}$ values using the same terms as above.

Fish community assemblages and associations regarding season and the dam wall were visualized using non-metric multidimensional scaling (nMDS) ordingation via 'vegan' (Okasanen et al. 2019). The community data matrix was compiled using the species counts from the survey and environmental data included was site, season and location to the dam wall, as in the analyses above. A one-way PERMANOVA using Bray-Curtis non-metric similarity and 999 permutations was then used to test for significant effects of environmental factors on fish species abundance. Community data was square-root transformed and Wisconsin double standardization was applied (vegan::metaMDS). Ordination stress was used to assess whether a two-dimensional ordination biplot was suitable to represent community data variation. Stress values $<0.15$ were considered appropriate (Quinn \& Keough 2002, Cousins et al. 2017). All statistical analyses were performed within the R software environment version 4.0.2 (R Core Team 2020).

\section{Results}

We sampled 18,289 specimens representing six orders, 13 families, and 23 fish species (Tables 2 and 3, Figures 3, 4 and 5). The order and family with the highest species richness, considering all reaches, were Characiformes and Characidae, respectively, followed by Cichliformes and Cichlidae, respectively (Figures 4 and 5). Nannostomus beckfordi Günther, 1872 was the most abundant species, with about 8,000 specimens sampled. Pimelodella parnahybae Fowler, 1941 and Hoplerythrinus unitaeniatus (Spix \& Agassiz 1829) were the rarest species represented, with only two specimens collected for each species (see appendix 1). We found the highest species richness at sample site (C2), with a total of 20 species, followed by $\mathrm{C} 1$ with $13, \mathrm{C} 5$ with 10 , $\mathrm{C} 4$ with 9, and C3 with only 2 (Table 3 ). Three putatively undescribed species were collected: Hemigrammus sp.1, Hemigrammus sp. 2, and Curimatopsis aff. cryptica. All of the collected species were small/ middle-sized native species as there were no exotic nor large-sized species collected in the studied area.

There were three categories of fishs based on their occurence: 1) Only found above the dam wall: Copella arnoldi (Regan, 1912), and Hemigrammus sp. 2; 2) only found below the dam: Astyanax cf. bimaculatus, Brachyhypopomus sp., Characidium sp., Hoplerythrinus unitaeniatus, Knodus victoriae (Steindachner, 1907), Moenkhausia oligolepis (Günther, 1864), Pimelodella parnahybae, Poecilia sarrafae Bragança \& Costa, 2011 and Steindachnerina notonota (Miranda Ribeiro, 1937); and 3) Above and below the dam: Anablepsoides vieirai Nelson, 2016, Apistogramma piauiensis Kullander, 1980, Cichlasoma cf. zarskei, Crenicichla brasiliensis (Bloch, 1792), Curimatopsis aff. cryptica, Gymnotus carapo Linnaeus, 1758, Hemigrammus sp. 1, Hoplias malabaricus (Bloch, 1794), Hyphessobrycon piorskii Guimarães, Brito, Feitosa \& Ottoni, 2018, Megalechis thoracata (Valenciennes, 1840), Nannostomus beckfordi and Synbranchus marmoratus Bloch, 1795 (see Table 3).

There was no interaction effect on Sprich by season and location to the dam wall, nor a main effect of season (Table 4, Figure 6). Location to the dam wall did have a significant main effect on Sprich, whereupon sites below the dam wall had higher Sprich than those above $(\mathrm{z}=1.90$, $p=0.05$; Table 4, Figure 6). There were no significant effects of any factors or interactions on Shannon diversity index $(\mathrm{H})$ or on Shannon evenness $\left(E_{H}\right)$ (Table 4, Figure 6).

The nMDs showed obvious distinctions in fish communities above and below the dam wall (Figure 7). The ordination stress was 0.05 and therefore appropriate to display on a two-dimensional scale and and acceptable representation of the community data. The PERMANOVA showed that the sample sites themselves contributed 
Oliveira, E.S. et al.

Table 2. List of species recorded for the Mata de Itamacaoca, upper Munim River basin, State of Maranhão, Brazil. The categories are defined as: native (N), endemic to the Hydrological units Maranhão and Parnaíba sensu Hubbert and Renno (2006) (E), widely distributed along Northeastern Brazil river basins (NE), probably undescribed species (U), with known distribution to the Amazon River basin (A), and widely distributed along several river basins of the Neotropical Region, including river basins located south to the Amazon River basin (W). Information obtained from Fricke et al. (2020b).

\section{CLASS/ORDER/FAMILY/GENUS/SPECIES}

\section{CLASS ACTINOPTERYGII}

\section{Order Characifomes}

Family Characidae

Astyanax cf. bimaculatus

$\mathrm{N}$

Hemigrammus sp. 1

$\mathrm{N}, \mathrm{U}$

Hemigrammus sp. 2

$\mathrm{N}, \mathrm{U}$

Hyphessobrycon piorskii Guimarães, Brito, Feitosa \& Ottoni, 2018

$\mathrm{N}, \mathrm{E}$

Knodus victoriae (Steindachner, 1907)

N, E

Moenkhausia oligolepis (Günther, 1864)

$\mathrm{N}, \mathrm{A}$

Family Crenuchidae

Characidium sp.

N

Family Curimatidae

Curimatopsis aff. cryptica

$\mathrm{N}, \mathrm{U}$

Steindachnerina notonota (Miranda Ribeiro, 1937)

Family Erythrinidae

Hoplerythrinus unitaeniatus (Spix \& Agassiz, 1829)

Hoplias malabaricus (Bloch, 1794)

Family Lebiasinidae

Copella arnoldi (Regan, 1912)

$\mathrm{N}, \mathrm{A}$

Nannostomus beckfordi Günther, 1872

N, A

Order Cichliformes

Family Cichlidae

Apistogramma piauiensis Kullander, 1980

N, E

Cichlasoma cf. zarskei Ottoni, 2011

$\mathrm{N}$

Crenicichla brasiliensis (Bloch, 1792)

$\mathrm{N}, \mathrm{NE}$

Order Cyprinodontiformes

Family Poeciliidae

Poecilia sarrafae Bragança \& Costa, 2011

N, E

Family Rivulidae

Anablepsoides vieirai Nelson, 2016

$\mathrm{N}, \mathrm{E}$

Order Gymnotiformes

Family Gymnotidae

Gymnotus carapo Linnaeus, 1758

$\mathrm{N}, \mathrm{W}$

Family Hypopomidae

Brachyhypopomus sp.

$\mathrm{N}$

Order Siluriformes

Family Callichthyidae

Megalechis thoracata (Valenciennes, 1840)

$\mathrm{N}, \mathrm{W}$

Family Heptapteridae

Pimelodella parnahybae Fowler, 1941

N, E

Order Synbranchiformes

Family Synbranchidae

Synbranchus marmoratus Bloch, 1795

N, W

$\mathrm{N}, \mathrm{W}$

(

(n)


Ichthyofauna of the Mata de Itamacaoca

Table 3. Species collected (X) in each collecting site (C1-C5) according to the Table 1 at Mata de Itamacaoca, upper Munim River basin, State of Maranhão, Brazil.

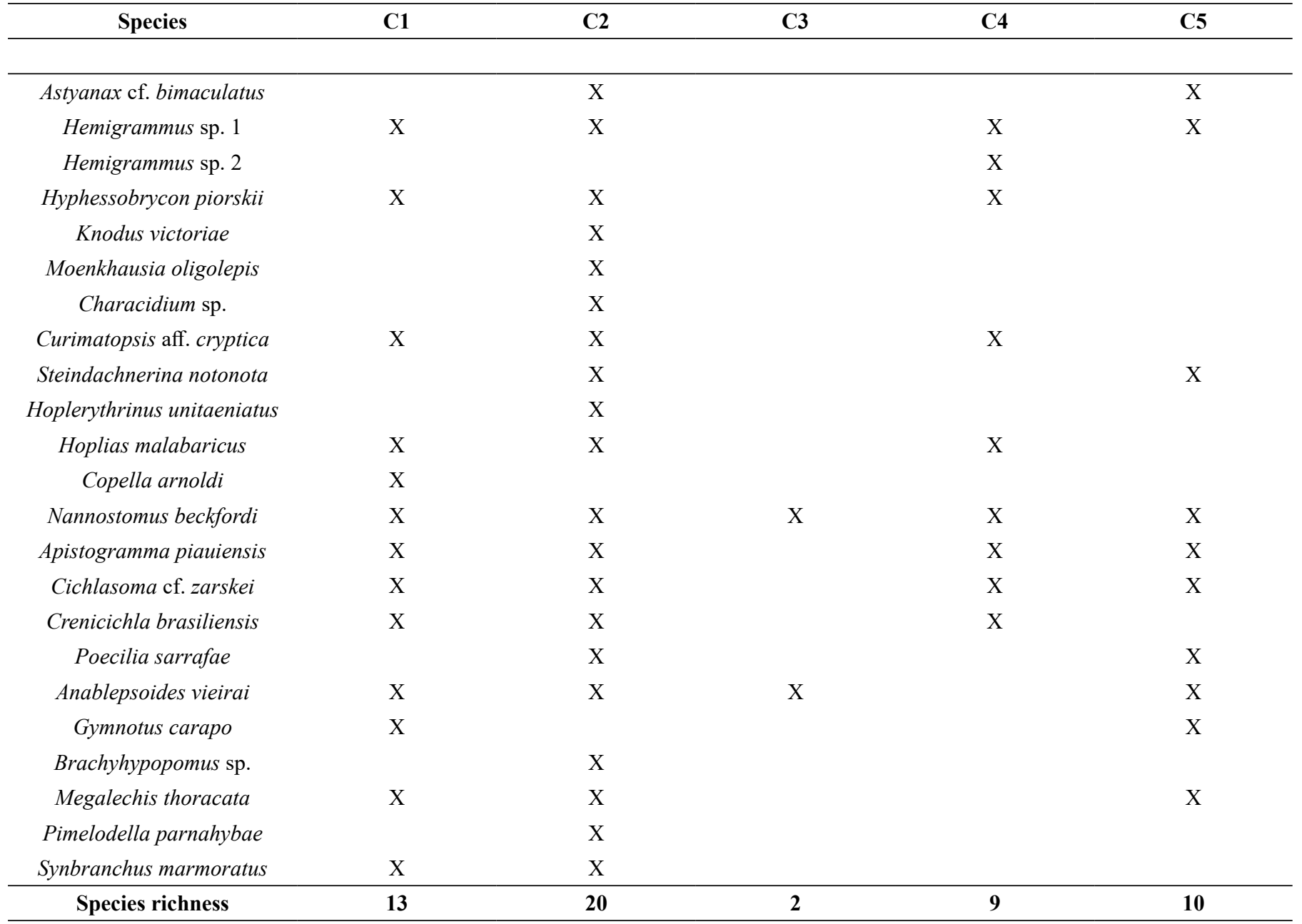

Table 4. Model terms for all factors and interactions from GLMs used to determine differences in a) species richness, b) Shannon-Weiner diversity index (H) and Shannon's evenness (EH). Significant p-values are highlighted in bold.

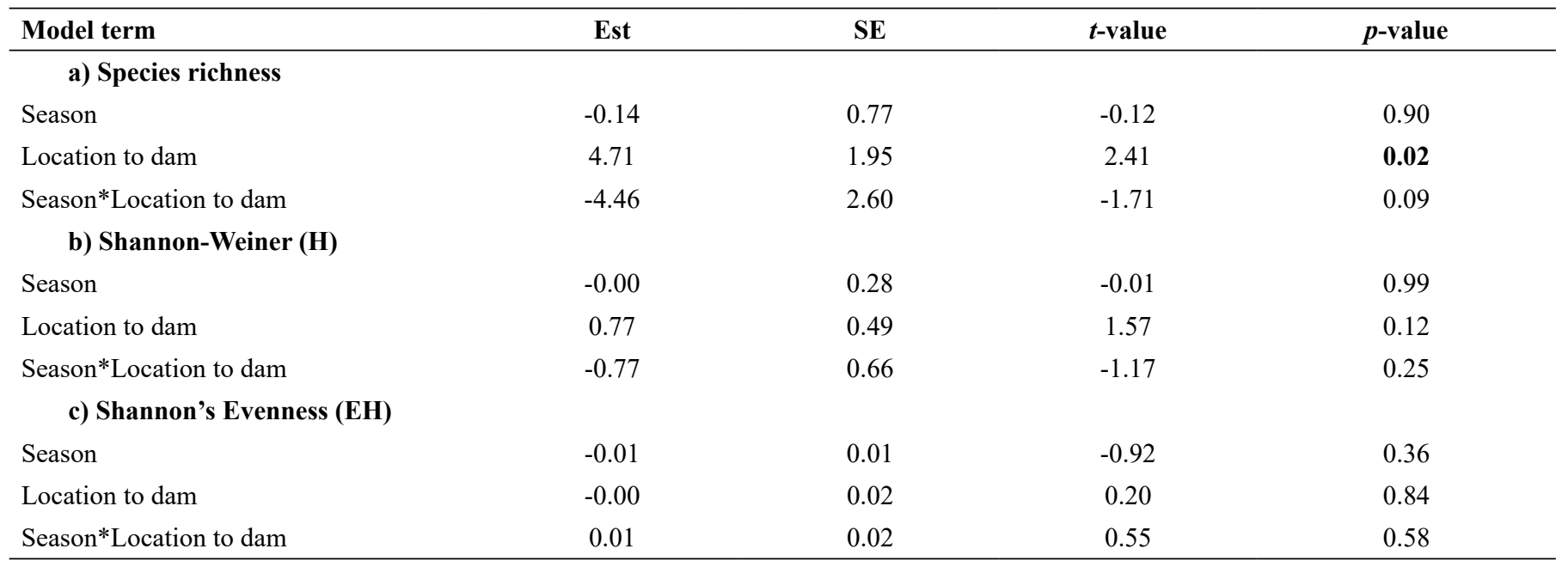




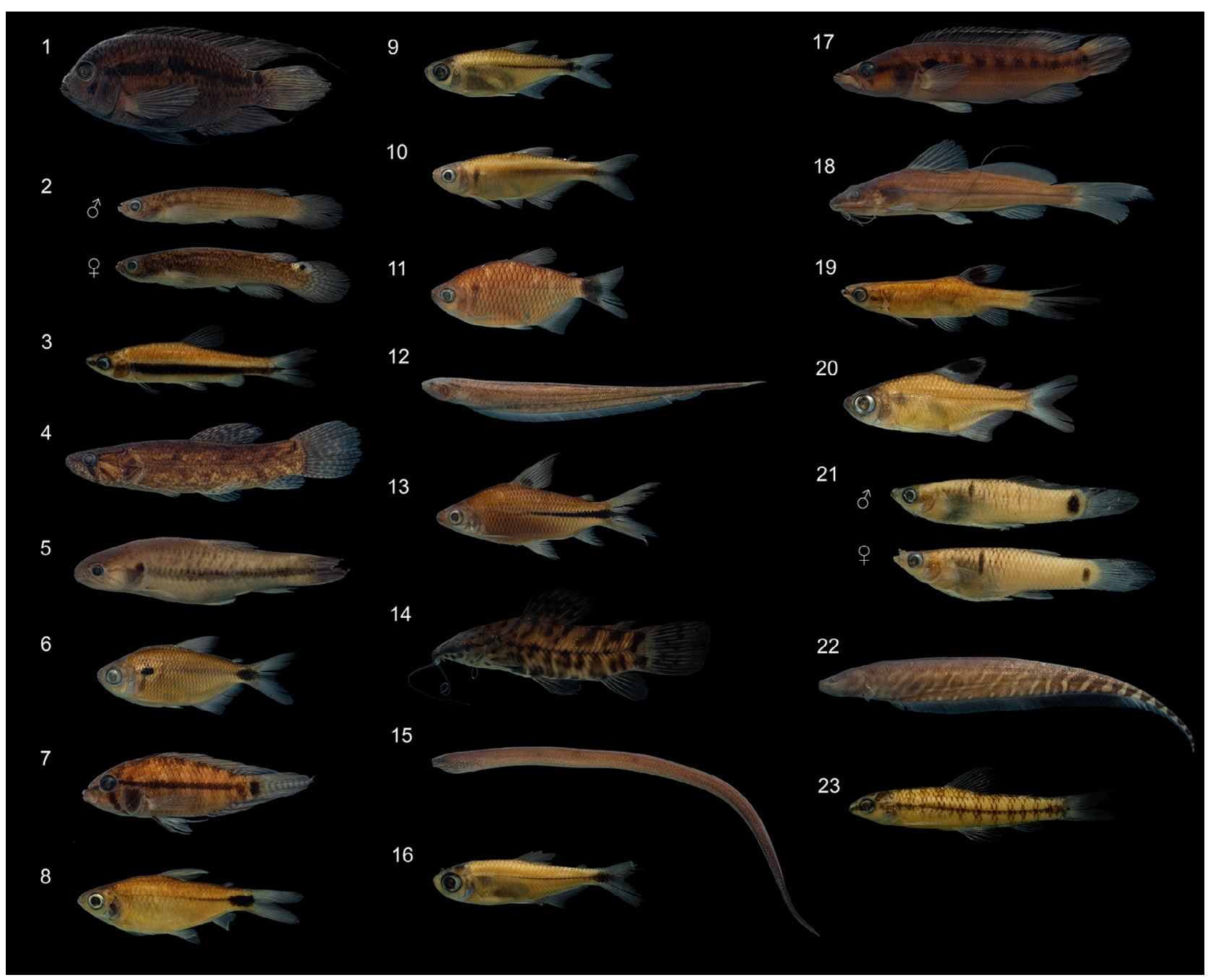

Figure 3. Fish species collected at Mata de Itamacaoca: 1- Cichlasoma cf. zarskei (CICCAA 03877, $97.3 \mathrm{~mm}$ SL), 2 - Anablepsoides vieirai (CICCAA 03729, male 29.9 and female $39.4 \mathrm{~mm} \mathrm{SL}$ ), 3- Nannostomus beckfordi (CICCAA 03732, $28.9 \mathrm{~mm}$ SL), 4- Hoplias malabaricus (CICCAA 03880, $96.2 \mathrm{~mm}$ SL), 5- Hoplerythrinus unitaeniatus (CICCAA 02512, 116.5 mm SL), 6- Astyanax cf. bimaculatus (CICCAA 03754, $54.2 \mathrm{~mm} \mathrm{SL}$ ), 7 - Apistogramma piauiensis (CICCAA04585, 39.9 mm SL), 8- Curimatopsis aff. cryptica (CICCAA 02014, $33.6 \mathrm{~mm} \mathrm{SL}$ ), 9 - Hemigrammus sp.1. (CICCAA 04593, 26.0 mm SL), 10 - Knodus victoriae (CICCAA 02466, 32.5 mm SL), 11- Moenkhausia oligolepis (CICCAA 04731, $53.1 \mathrm{~mm} \mathrm{SL}$ ), 12 - Brachyhypopomus sp. (CICCAA 02457, $95.1 \mathrm{~mm}$ TL), 13- Steindachnerina notonota (CICCAA 04729, $67.15 \mathrm{~mm} \mathrm{SL}$ ), 14 - Megalechis thoracata (CICCAA 03447, $47.5 \mathrm{~mm} \mathrm{SL}$ ), 15 - Synbranchus marmoratus (CICCAA 03400, $137.8 \mathrm{~mm}$ TL), 16 - Hemigrammus sp.2 (CICCAA 02555, 22.9 mm SL), 17 - Crenicichla brasiliensis (CICCAA 03402, $104.3 \mathrm{~mm}$ SL), 18 - Pimelodella parnahybae (CICCAA 03753, 60.1 mm SL), 19 Copella arnoldi (CICCAA 00081, $26.2 \mathrm{~mm}$ SL), 20 - Hyphessobrycon piorskii (CICCAA 02421, $22.7 \mathrm{~mm} \mathrm{SL),} 21$ - Poecilia sarrafae (CICCAA 02506, male 20.6 and female $24.5 \mathrm{~mm} \mathrm{SL}$ ), 22 - Gymnotus carapo (CICCAA 00879, $96.8 \mathrm{~mm}$ TL), and 23 - Characidium sp. (CICCAA 03751, 26.1 mm SL). Photographed by Felipe Ottoni.

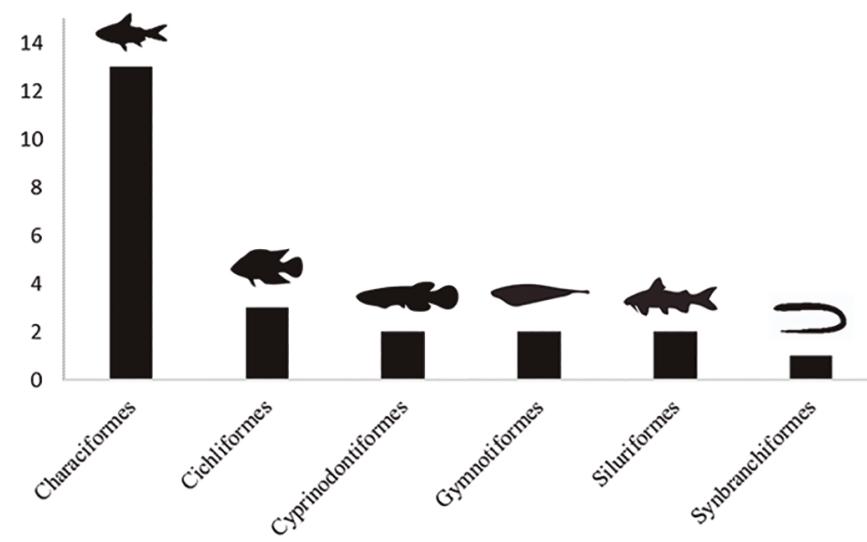

Figure 4. Ranking of richness by orders observed in the studied area. The numbers in the left column correspond to the number of species.

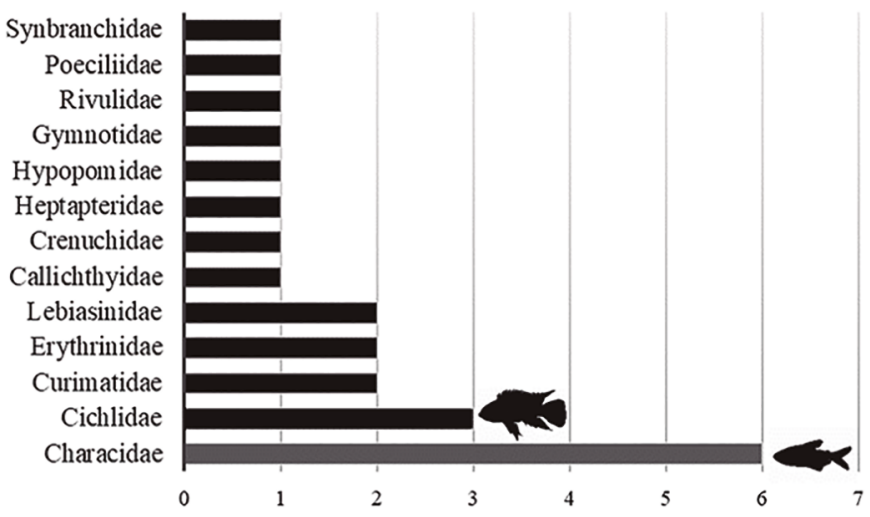

Figure 5. Ranking of richness by families observed in the studied area. The numbers below the graphic correspond to the number of species. The grey bar evidences the most species-rich family of this study. 


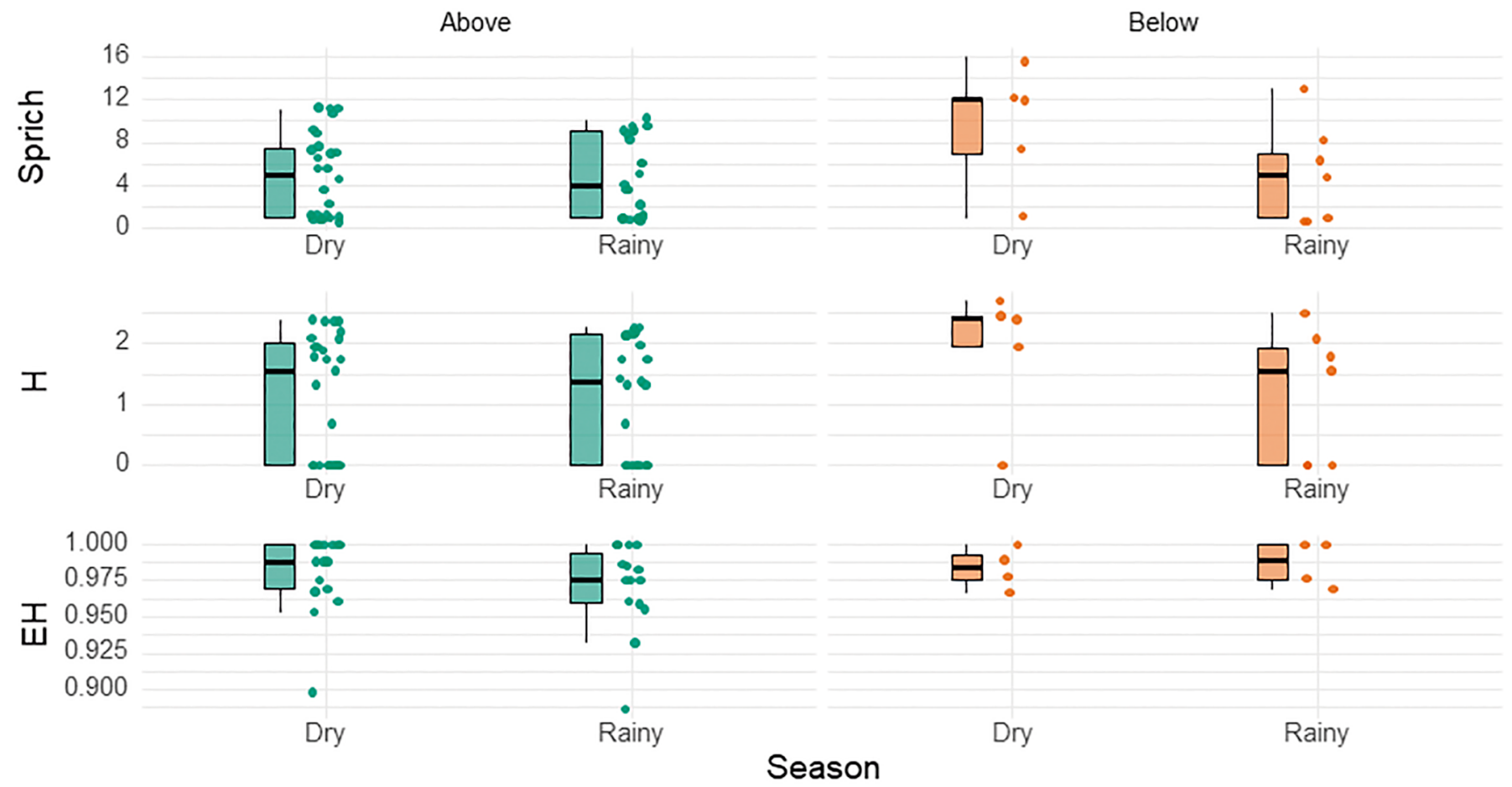

Figure 6. Species richness (Sprich), Shannon-Weiner diversity $(\mathrm{H})$, and Shannon's Evenness (EH) of sampling sites in the dry and rainy seasons, above and below the dam wall. Boxplot indicates median and inter-quartile ranges while points indicate species richness per site.

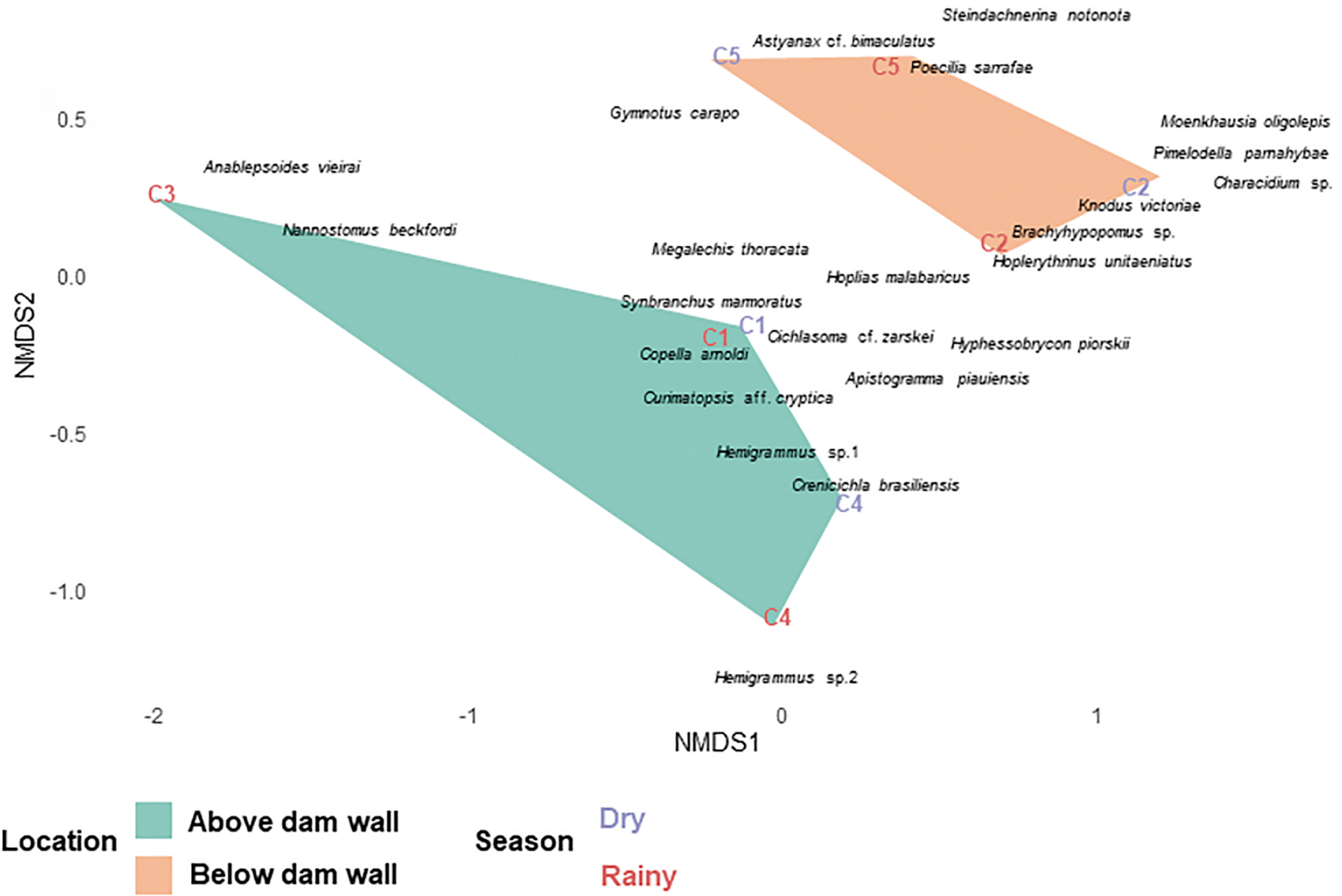

Figure 7. Biplot of nMDS ordination of fish communities of the Mrn above and below the dam wall in dry and rainy seasons. Convex hulls denote sites with relation to the dam wall. 
to $70 \%$ of the variance in fish community $\left(\mathrm{R}^{2}=0.70, \mathrm{~F}_{3,8}=11.00, \mathrm{p}<\right.$ 0.001 ), and position to the dam wall was responsible for $18 \%$ of the variance $\left(\mathrm{R}^{2}=0.18, \mathrm{~F}_{3,8}=8.54, \mathrm{p}<0.01\right)$. Season did not have an effect on fish community $\left(\mathrm{R}^{2}=0.04, \mathrm{~F}_{3,8}=2.26, \mathrm{p}=0.13\right)$.

\section{Discussion}

The Mrn urban protected area appears to have efficiently conserved freshwater fish biodiversity, as all of the 23 fish species registered to in the study area are native species (there are no introduced species). Another curious fact is the absence of large-sized species in the studied area. This could be explained by the history of the construction of the dam, which was formed by the damming of small streams, not including originally large rivers. In addition to the high sampling effort, information provided by local fishermen confirms the absence of large-sized fish species in the area. Small-sized fish species are the most threatened among the Neotropical freshwater fish fauna (smallsized fish species comprise around 250 species - about $80 \%$ - of the total endangered fish species). This size class of fish represents about $70 \%$ of fish species richness of the Neotropical Region, however, they are usually overlooked by the general public as well as conservation agencies and organizations in favour of large charismatic species (Kalinkat et al. 2017). Further, threats to small fish species are enhanced due to their habitats being far smaller, often fragmented, linear systems that are usually more vulnerable to human impacts (Arthington et al. 2016, Castro \& Polaz 2020). Generating robust baseline data of ecological, biological, geographic distributional and taxonomic aspects of these species ought to be a conservation priority, especially in understudied Neotropical regions.

The Mata da Itamacaoca is an urban protected area from the upper Munim River basin, Northern Brazilian, located at the Municipality of Chapadinha-MA, in the Northern Brazilian Cerrado. This protected area is efficient in protecting freshwater biodiversity, since it includes not only the main tributaries of the area, but also the reservoir itself aswell as associated springs (Azevedo-Santos et al. 2018). This has protected the system from a series of urban impacts in this protected area, such as pollution and introduced species, which are present in tributaries, rivers and small streams not included in the protected area. The designated area was specifically designated by the CAEMA(Companhia de Saneamento Ambiental do Maranhão) with the aim to supply the city of ChapadinhaMA with water (including potable water) (Silva et al. 2008). The CAEMA built the reservoir to store water for use during the regions severe dry season, thus providing the city with access to water throughout the year. The region where the dam was created was composed of several streams and spring, the main one being the Itamacaoca stream (Silva et al. 2008) and includes streams and fountains in the vicinity to prevent the water pollution of the reservoir. While the study area is currently in pristine condition with regards to non-native alien species, the proximity to the city, Brazilian legislation changes and the nature of the reservoir puts the protected area at risk of invasion in the future (Garcia et al. 2017, Pelicice et al. 2018, Geller et al. 2020). Dams can act as invasion hubs as well as modifying environmental conditions which allow non-native species to proliferate, all of which can contribute towards biotic homogenisation (Bunn \& Arthington 2002, Daga et al. 2020), as well as acting as a barrier for natural species, which are restricted to parts above or below the dam. Indeed, the clear different fish community composition above and below the dam wall indicates that despite the comparable species diversity and richness, there is evidence of alteration in the communities. Future work should identify whether these communities are also separated in terms of functional trait based metrics, as this can provide information on community resilience and biotic resistance (Moyle \& Light 1996, Olden et al. 2010, Brito et al. 2020).

None of the species inventoried in the present study have the status of threat of extinction (ICMBIO, 2018). Some species could not be categorized because we were unable to reach species-level identification, or were described after the publication of the red book. However, the species Hyphessobrycon piorskii recorded by the present study is probably not threatened with extinction, since it does not have a restricted distribution and also occurs in another federal protected area, the Lençóis Maranhenses National Park (Guimarães et al. 2018b, 2019, Brito et al. 2019, 2020).

The order and family with the highest species richness in the Mata de Itamacaoca, was Characiformes and Characidae, respectively, followed by Cichliformes and Cichlidae, respectively. Characiformes and Characidae are usually the most species-rich groups (Order and Family, respectively) found in any freshwater fish survey of the Neotropical Region. Usually, the second most representative Order is Silurifomes (e.g. Lucinda et al. 2007, Ferreira et al. 2011, Claro-García \& Shibatta 2013, Ramos et al. 2014). This trend diverges in the Mata de Itamacaoca, where Cichliformes and Cichlidae (Order and Family, respectively) are the second most diverse groups. This difference found here in the composition pattern of the fish community is probably due to the absence of the Family Loricariidae in the studied area, which is usually one of the most representative freshwater fish families in Neotropical region inventories (e.g. Lucinda et al. 2007, Ferreira et al. 2011, Claro-García \& Shibatta 2013, Ramos et al. 2014).

Published studies on fish inventories and taxonomic studies are very scarce in the upper Munim River basin. Recently, two new species were described which occur in the river portion (Guimarães et al. 2018a,b). However, only Hyphessobrycon piorskii occurs at Mata the Itamacaoca, including type material (see Appendix 1, Tables 2 and 3, Figure 5, Guimarães et al. 2018b). The dataset from the present study documented more species than previous work by Ribeiro et al. (2014) and Nunes et al. (2019) which list between 15-20 middle to large sized species present in the upper Munim River basin, of which, the majority of the species were not the same. Comparing the present study to Ribeiro et al. (2014) only four species were the same: Crenicichla brasiliensis [Crenicichla menezesi Ploeg, 1991 in Ribeiro et al. (2014)], Hoplias malabaricus, and Synbranchus marmoratus. Whereas, compared to Nunes et al. (2019), only three species were the same: Astyanax cf. bimaculatus, Crenicichla brasiliensis, and Hoplias malabaricus. This study represents the first time that an ictythological survey conducted at the upper Munim River basin has presented photographs of all of the recorded species and provided specific voucher number for each examined fish lot. By including this type of information it promotes transparency by allowing other researchers to confirm the identifications, as well as facilitating further research by providing a much needed resource for fish identification. Currently, besides the present study, any records of fish inventories for the Mrn, which include illustrations, let alone photographs of the species collected are rare (e.g. Soares, 2013, Matavelli et al. 2015, Piorski et al. 2017). 
We found the highest species richness at collecting site (C2), with a total of 20 species, followed by $\mathrm{C} 1$ with $13, \mathrm{C} 5$ with $10, \mathrm{C} 4$ with 9 , and $\mathrm{C} 3$ with only 2 (see Appendix 1). The collecting sites C1, C2, C3 and $\mathrm{C} 5$ have the most preserved ecological integrity, while $\mathrm{C} 4$ (the reservoir) is the most modified area in relation to the original conditions. The reservoir dam inhibits dispersion of fishes occurring in $\mathrm{C} 2$, which is located below the reservoir dam. It is likely that this is driving the greater species richness in $\mathrm{C} 2$ compared to $\mathrm{C} 1, \mathrm{C} 3$ and $\mathrm{C} 4$. One other site, $\mathrm{C} 5$, is also located below the reservoir dam, however, its lower species richness compared to $\mathrm{C} 2$ could be explained by two reasons. Firstly, this collecting site was less sampled than $\mathrm{C} 2$, and secondly it dries almost completely during the dry season, while $\mathrm{C} 2$ is permanently inundated. The low number of species in C3 is likely to be due to the sample being collected in one collection expedition due to issues in access to the site.

There were three categories of fishes based on their occurrence: 1) only found above the dam wall, 2) only found below the dam, and 3) above and below the dam. Despite these three distinct categories, it was not possible to observe any ecological pattern that correlates these species with these three distribution patterns. Similarly, despite the different fish community composition above and below the dam wall there is no concrete evidence nor immediate explanation for this. This is compounded by the regional data deficit and lack of historical data prior to the dam construction. Nonetheless, it is important to emphasize that the absence of Anablepsoides vieirai and Copella arnoldi at locality $\mathrm{C} 4$ was already expected, due to the ecological requirements of these species, which do not occur in this type of environment. In addition, the absence of Pimelodella parnahybae in the rainy season could be explained because catfishes usually inhabit caves or burrows and are usually associated with the benthos. As in the dry season the water level is lower, it is easier to collect catfishes, since we can access the bottom of the river more easily. Possible reasons for this differentiation, which ought to be further explored, are the effects of habitat filtering, river continuum concept and functional traits of the fish community. This research would further both the conservation of Neotropical freshwaters but also challenge or confirm whether these concepts subscribe to theories that have generally been developed in temperate systems and have data gaps in the tropics (Boulton et al. 2008, Dudgeon 2008, Sternberg \& Kennard, 2013).

From the 23 species herein recorded, we were not able to accurately identify seven species to the species level. Three of them correspond to new species (Curimatopsis aff. cryptica, Hemigrammus sp.1, and Hemigrammus sp.2), and are in the process of being described. The other four species need a more comprehensive taxonomic investigation, especially comparing with specimens from other populations from other river basins and regions, as already proposed for other fish groups occurring along the coastal river basins of the State of Maranhão by Guimarães et al. (2020). The State of Maranhão (northeastern Brazil), compared to other Brazilian regions, has distinctly few studies related to its freshwater ichthyofauna, especially in taxonomic studies (Piorski, 2010, Guimarães et al. 2018a, 2020). Thus, at the outset it was anticipated that some species would remain taxonomically indeterminate in this study and therefore was a motivation for carrying out this inventory. Of the other 16 species we were able to identify accurately at the species level, six of them are endemic to the Hydrological units Maranhão and Parnaíba sensu Hubbert and Renno (2006) (hereafter Mrn and Prn, respectively). Two are widely distributed along Northeastern Brazil river basin. Five are widely distributed along several river basins of the Neotropical Region, including river basins located south to the Amazon River basin, and three also have their known distribution to the Amazon River basin. Therefore, we would like to emphasize that a significant number of the species registered here are endemic to the Mrn and Prn; and in addition, the composition of the ichthyofauna in the studied area has little influence from the Amazon basin. Thus, the present study contributes considerable addition to the knowledge around endemic small sized fishes. This information is integral for future planning and conservation endeavours as these species are disproportionately at risk (Arthrington et al. 2016). Further, our data mirrors trends seen in other tropical protected areas, wherein the fish species diversity is as yet undescribed but under high potential risk (Rico-Sánchez et al. 2020).

Considering the small size and similarity oh habitats within the sampled area, the diversity of fish species found in the Mata de Itamacaoca was surprisingly high. Comparing the number of species found by our study ( 23 species) with other studies that carried out inventories of entire river basins or much larger areas of the region. For example, Barros et al. (2011) (69 species) and Nascimento et al. (2016) (64 species) both inventoried the fish fauna of the entire Itapecuru River basin, a of the significant coastal river basins of the Mrn and Prn. Further, Brito et al. $(2019,2020)$ inventoried 56 species of freshwater fish from the Parque Nacional dos Lençóis Maranhenses and the adjacent areas. Therein, the Mata de Itamacaoca holds around a third of the number of the species reported in far larger systems, thus demonstrating the importance of the studied area in the protection of the fish fauna inhabiting it.

\section{Conclusions and Future Perspectives}

This study corroborates other studies carried out in the Mrn that the ichthyofauna of this region still has many knowledge gaps, especially concerning the composition and taxonomy of the fish groups occurring in the basins. Especially regarding the diversity of small-sized fishes (Piorskii 2010, Guimarães et al. 2018a). The present study reveals three species not yet described in this study area, and one species recently described (in 2018). This shows the potential of the region in still having freshwater fish species which need a formal description. In addition, the fact that small streams can host a comparatively high species richness combined with the possibility of finding endemic and undescribed fish species emphasises need for these environments to be treated as priority in conservation policies. Further work should focus on the diversity of neglected small sized fish species with particular focus on taxonomy and community ecology in vulnerable Mrn stream environments. All species listed here are small and medium sized and some attention is needed for these species (Castro \& Polaz 2020). Problems like the lack of knowledge about them, as well as the reduction of the original riparian vegetation cover lead to changes that affect the existence of these smaller species (Castro \& Polaz 2020). An important facet to note is the success in the protected area designation, which is currently free 
from harmful non-native species. With this respect, this area appears to be a valuable refuge for small fish species. Moreover, due to the constant anthropogenic change, this study may be a baseline for similar environments in the region as it presents a native fish assemblage unaffected by biotic drivers yet exposed to other abiotic drivers.

\section{Supplementary Material}

The following online material is available for this article:

Appendix 1 - Examined material

\section{Acknowledgements}

We thank Antônio Bezerra, Brenda Furtado, Beatriz Costa, Camilla Marques, Marciara Lopes, Ianca Gouvêa, Ivanilda Nascimento, João Reis, Junior Rodrigues, Maurício Paiva, Marcony Coelho, Maria Bastos, Olivia Castro, Railda Gomes, Revangivaldo Sousa, Rayane Aguiar, Riccardo Mugnai, Rozijane, Fernandes, Shyrley Viana, Thayna Costa, Thayanara Lages, Valquíria Carneiro, and Vanessa Batista for collecting part the examined material; Filipe RangelPereira (UFRJ) and André Netto-Ferreira (UFRGS) for helping us with the identification of the Gymnotiformes species and Copella arnoldi, respectivelly; and CAPES (Coordenação de Aperfeiçoamento de pessoal de nível Superior - Finance Code 001) and FAPEMA for providing the scholarship to ESO, ECG, PSB, LOV, under the process 88882.445735/2019-01, BD-05604/19, 88887.159561/201700, respectively, and APP-UNIVERSAL-00754/13 to JLSN. JS acknowledges funding from the DSI-NRF Centre of Excellence for Invasion Biology (CIB).

All material was collected with permits 54949, 57787, 64415, and 67594 from SISBIO (Brazilian Institute of Environment and Natural Resources).

\section{Author Contributions}

Elioenai da Silva Oliveira: Specimen Collection, expedition organization, data analysis, statistical analysis, manuscript writing.

Erick Cristofore Guimarães: Specimen Collection, expedition organization, data analysis, specimens identification, manuscript writing.

Pâmella Silva de Brito: Specimen Collection, expedition organization, data analysis, specimens identification, manuscript writing.

Lucas de Oliveira Vieira: Specimen Collection, expedition organization, data analysis, specimens identification.

Rafael Ferreira de Oliveira: Specimen Collection, expedition organization, data analysis, specimens identification.

Diego Sousa Campos: Specimen Collection, expedition organization, data analysis, specimens identification, map preparation.

Axel Makay Katz: Specimens identification, data analysis, image preparation, manuscript writing.

Josie South: Data analysis, Statistical analysis, manuscript writing, language revision.

Jorge Luiz Silva Nunes: Specimen Collection, expedition organization, data analysis, manuscript writing.
Felipe Polivanov Ottoni: Specimen Collection, expedition organization, data analysis, specimens identification, manuscript writing, project financing.

\section{Conflicts of Interest}

The authors declare that they have no conflict of interest.

\section{References}

AGOSTINHO, A.A., PELICICE, F.M. \& GOMES L.C. 2008. Dams and the fish fauna of the neotropical region: impacts and management related to diversity and fisheries. Braz. J. Biol. 68(4): 1119-1132. doi: 10.1590/ S1519-69842008000500019

ARTHINGTON, A.H., DULVY, N.K., GLADSTONE, W. \& WINFIELD, I.J. 2016. Fish conservation in freshwater and marine realms: status, threats and management. Aquat. Conserv.: Mar. Freshw. Ecosyst. 26 (5): 838-857. doi: $10.1002 /$ aqc. 2712

AZEVEDO-SANTOS, V.M., FREDERICO R.G., FAGUNDES, C.K., POMPEU, P.S., PELICICE, F.M., PADIAL, A.A., NOGUEIRA, M.G., FEARNSIDE, P.M., LIMA, L.B., DAGA, V.S., OLIVEIRA, F.J.M., VITULE, J.R.S., CALLISTO, M., AGOSTINHO, A.A., ESTEVES, F.A., LIMA-JUNIOR, D.P., MAGALHÃES, A.L.B., SABINO, J., MORMUL, R.P., GRASEL, D., ZUANON, J., VILELLA, F.S. \& HENRY, R. 2019. Protected areas: A focus on Brazilian freshwater biodiversity. Divers. Distrib. 25 (3): 442-448. 1-7. doi: 10.1111/ddi.12871

BARROS, M.C., FRAGA, E.C. \& BIRINDELLI, J.L.O. 2011. Fishes from the Itapecuru River basin, State of Maranhão, northeast Brazil. Braz. J. Biol. 71(2): 375-380. doi: 10.1590/S1519-69842011000300006

BIRINDELLI, J.L.O. \& SIDLAUSKAS, B.L. 2018. Preface: How Far Has Neotropical Ichthyology in Twenty Years? Neotropical Ichthyology 16(3): E180128. doi: 10.1590/1982-0224-20180128

BOULTON, A.J, BOYERO, L., COVICH, A.P., DOBSON, M., LAKE, S. \& PEARSON, R. 2008. Are Tropical Streams Ecologically Different from Temperate Streams? In: Dudgeon, D. (ed) Tropical Stream Ecology. Academic Press, London. pp:273 - 294.

BRITO, M.F.G., DAGA, V.S. \& VITULE J.R.S. 2020. Fisheries and biotic homogenization of freshwater fish in the Brazilian semiarid region. Hydrobiologia. doi: 10.1007/s10750-020-04236-8

BRITO, P.S., GUIMARÃES, E.C., FERREIRA, B.R.A., OTTONI, F.P. \& PIORSKI N.M. 2019. Freshwater fishes of the Parque Nacional dos Lençóis Maranhenses and adjacent areas. Biota Neotropica. 19(3): E20180660. doi: 10.1590/1676-0611-bn-2018-0660

BRITO, P.S., GUIMARÃES, E.C., FERREIRA, B.R.A., SANTO, S J.P., AMARAL, Y.T. \& OTTONI F.P. 2020. Updated and supplementary data on Brito et al. (2020): Freshwater Fishes of the Parque Nacional dos Lençóis Maranhenses and adjacent areas. Ichthyological Contributions of Pecescriollos 73: 1-17.

BROOK, B.W. \& BRADSHAW, C.J.A. 2006. Momentum Drives the Crash: Mass Extinction in the Tropics. Biotropica 38 (3): 302-305. doi: 10.1111/j.17447429.2006.00141.x

BROOKS, T.M., MITTERMEIER, R.A., MITTERMEIER, C.G., DA FONSECA, G.A.B., RYLANDS, A.B., KONSTANT, W.R., FLICK, P., JOHN, P., OLDFIELD, S., MAGIN, G., \& HILTON-TAYLOR C. 2002. Habitat loss and extinction in the hotspots of biodiversity. Conserv. Biol. 16(4): 909-923. doi: 10.1046/j.1523-1739.2002.00530.x

BUCKUP, P.A., MENEZES, N.A. \& GHAZZI, M.S. 2007. Catálogo das espécies de peixes de água doce do Brasil. Museu Nacional, Rio De Janeiro.

BUNN, S.E. \& ARTHINGTON, A.H. 2002. Basic principles and ecological consequences of altered flow regimes for aquatic biodiversity. J. Environ. 30 (4): 492-507. doi: 10.1007/s00267-002-2737-0

CASTRO, R.M.C. \& POLAZ, C.N.M. 2020. Small-Sized Fish: The largest and most threatened portion of the megadiverse neotropical freshwater fish fauna. Biota Neotropica. 20(1): E20180683. doi: 10.1590/1676-0611Bn-2018-0683 
CLARO-GARCIA, A. \& SHIBATTA, O.A. 2013. The fish fauna of streams from the upper rio Tocantins basin, Goiás State, Brazil. Check List. 9(1): 028-033. doi: 10.15560/9.1.28

CLOSE, B., BANISTER, K., BAUMANS, V., BERNOTH, E.M., BROMAGE, N., BUNYAN, J., ERHARDT, W., FLECKNELL, P., GREGORY, N., HACKBARTH, H., MORTON, D. \& WARWICK, C. 1996. Recommendations for euthanasia of experimental animals: Part 1. DGXI of the European Commission. Laboratory Animals 30: 293-316. doi: $10.1258 / 002367796780739871$

CLOSE, B., BANISTER, K., BAUMANS,V., BERNOTH, E.M., BROMAGE, N., BUNYAN, J., ERHARDT, W., FLECKNELL, P., GREGORY, N., HACKBARTH, H., MORTON, D. \& WARWICK, C. 1997. Recommendations for euthanasia of experimental animals: Part 2. DGXI of the European Commission. Laboratory Animals 31: 1-32. doi: $10.1258 / 002367797780600297$

COSTA, W.J.E.M., AMORIM, P.F. \& MATTOS, J.L.O. 2012 Species delimitation in annual killifishes from the Brazilian Caatinga, the Hypsolebias flavicaudatus complex (Cyprinodontiformes: Rivulidae): implications for taxonomy and conservation. System. Biodivers. 10(1): 71-91. doi: 10.1080/14772000.2012.664177

COUSINS, S., KENNARD, M.J. \& EBNER, B.C. 2017. Depth-related composition and structuring of tropical riverine fish assemblages revealed by baited video. Mar. Freshw. Res. 68(10) :1965-1917. doi: 10.1071/ MF16278

DARWALL, W., BREMERICH, V., WEVER, A., DELL, A. I., FREYHOF, J., GESSNER, M. O. \& WEY,L O. 2018. The Alliance for Freshwater Life: A global call to unite efforts for freshwater biodiversity science and conservation. Aquat Conserv. 28: 1015-1022. doi: 10.1002/aqc.2958

DAGA, V.S., AZEVEDO-SANTOS, V.M., PELICICE, F.M, FEARNSIDE, P.M., PERBICHE-NEVES, G., PASCHOAL, L.R.P., CAVALLARI, D.C., ERICKSON, J., RUOCCO, A.MC., OLIVEIRA, I.,PADIAL, A.A. \& VITULE, J.R.S. 2020. Water diversion in Brazil threatens biodiversity. Ambio. 49(1): 165-172. doi: 10.1007/s13280-019-01189-8

Decreto $N^{\circ}$ 05/2018, 23 de Março de 2018. Dispõe sobre a criação de área de Relevante Interesse Ecológico (Arie) Itamacaoca. Prefeitura Municipal de Chapadinha, Maranhão, MA.

DUDGEON, D., ARTHINGTON, A.H., GRESSNER, M.O., KAWABATA, Z-I., KNOWLER, D.J., LÉVÊQUE, C., NAIMAN, R.J., PRIEUR-RICHARD, A.H., SOTO, D., STIASSNY, M.L. \& SULLIVAN, C.A. (2007) Freshwater biodiversity: importance, threats, status and conservation challenges. Biol. Rev. 81(2): 163-182. doi: 10.1017/S1464793105006950

DUDGEON D. (ed.). (2008). Tropical Stream Ecology. Elsevier Academic Press. London. pp. 340.

FERREIRA, E., ZUANON, J., SANTOS, G. \& AMADIO, S. 2011. The fish fauna of the Parque Estadual do Cantão, Araguaia River, State of Tocantins, Brazil. Biota Neotropica 11 (2): 277-284. doi: 10.1590/S1676-06032011000200028

FRICKE, R., ESCHMEYER, W. N. \& FONG, J. D. 2020a Species by Family/ Subfamily. Available in: http://researcharchive.calacademy.org/research/ ichthyology/catalog/SpeciesByFamily.asp Accessed in 17 May 2020.

FRICKE R., ESCHMEYER W.N. \& VAN D.L.R. 2020b. Catalog of Fishes: Genera, Species, Refereces. Electronic version. Available in: http:// researcharchive.calacademy.org/research/ichthyology/catalog/fishcatmain. asp Accessed in 18 May 2020.

FROTA, A., MESSAGE, H.J., OLIVEIRA, R.C., BENEDITO, E. \& GRAÇ, W.J. 2019. Ichthyofauna of headwater streams from the rio Ribeira de Iguape basin, at the Boundaries of the Ponta Grossa Arch, Paraná, Brazil. Biota Neotropical. 19(1): E20180666 doi: 10.1590/1676-0611- bn-2018-0666

GARCIA, D.A.Z., BRITTON, J.R., VIDOTTO-MAGNONI, A.P. \& ORSI, M.L. 2018. Introductions of non-native fishes into a heavily modified river: rates, patterns and management issues in the Paranapanema River (Upper Paraná ecoregion, Brazil). Biol. Invasions. 20(5): 1229-1241. doi: 10.1007/ s10530-017-1623-x

GELLER, I.V., GARCIA, D.A.Z., CASIMIRO, A.C.R., PEREIRA, A.D., JARDULI, L.R., VITULE, J.R.S AZEVEDO, R.F. \& ORSI, M.L. 2020. Good intentions, but bad effects: Environmental laws protects non-native ichthyofauna in Brazil. Fish. Manag. Ecol. 00: 1-4. doi: 10.1111/fme. 12446
GUIMARÃES, E.C., BRITO, P.S., FERREIRA, B.R. \& OTTONI, F.P. 2018A. A new species of Charax (Ostariophysi, Characiformes, Characidae) from northeastern Brazil. Mitt. Mus. Naturkunde Berl., Zoolog. Reihe. 94(1): 83-93. doi: 10.3897/zse.94.22106

GUIMARÃES, E.C., BRITO, P.S., FEITOSA, L.M., CARVALHO-COSTA, L.F. \& OTTONI, F.P. 2018b. A new species of Hyphessobrycon Durbin from northeastern Brazil: evidence from morphological data and DNA barcoding (Characiformes, Characidae). ZooKeys. 765: 79-101. doi: 10.3897/zookeys.765.23157

GUIMARÃES E.C., DE BRITO P.S., FEITOSA L.M., CARVALHO-COSTAL.F. \& OTTONI F.P. 2019. A new cryptic species of Hyphessobrycon Durbin, 1908 (Characiformes, Characidae) from the Eastern Amazon, revealed by integrative taxonomy. Zoosystematics and Evolution 95 (2): 345-360. https:// doi.org/10.3897/zse.95.34069

GUIMARÃES, E.C., BRITO, P.S., GONÇALVES, C.S. \& OTTONI, F.P. 2020. An inventory of Ichthyofauna of the Pindare River drainage, Mearim River basin, Northeastern Brazil. Biota Neotropica. 20 (4): e20201023. https:// doi.org/10.1590/1676-0611-bn-2020-1023

HARRISON, I., ABELL, R., DARWALL, W., THIEME, M. L., TINCHNER, D. \& TIMBOE, I. 2018. The Freshwater Biodiversity Crisis. Science. 362: 1369. doi: $10.1126 /$ science.aav 9242

HE, F., ZARFL, C., BREMERICH, V., DAVID, J.N., HOGAN, Z., KALINKAT, G., TOCKNER, K. \& JÄHNIG, S.C. 2019. The global decline of freshwater megafauna. Glob. Chang. Biol. 25(11): 3883-3892. doi: 10.1111/gcb.14753

HUBERT, N. \& RENNO, J.F. 2006. Historical Biogeography of South American Freshwater Fishes. J. Biogeogr. 33: 1414-1436. doi: 10.1111/J.13652699.2006.01518.X

INSTITUTO CHICO MENDES DE CONSERVAÇÃO DA BIODIVERSIDADE (ICMBIO). 2018. Livro Vermelho da Fauna Brasileira Ameaçada de Extinção: Volume I/1. ed. Brasília.

KALINKAT, G. \& JÄHNIG, S.C., JESCHKE J.M. 2017. Exceptional body size-extinction risk relations shed new light on the freshwater biodiversity crisis. Proc. Natl. Acad. Sci. U.S.A. 114(48): E10263-E10264. doi: 10.1073/ pnas. 1717087114

LEARY, S, UNDERWOOD, W., ANTHONY, R., CARTNER, S, COREY, D., GRANDIN, T, GREENACRE, C.B., GWALTNEY-BRAN, S., MCCRACKIN, M.A., MEYER, R., MILLER, D., SHEARER, J. \& YANONG, R. 2013. AVMA Guidelines for the Euthanasia of Animals: 2013 Edition. Retrieved from: http://works.bepress.com/cheryl_greenacre/14.

LAURENCE, W.F. 2007. Have we overstated the tropical biodiversity crisis? Trends Ecology and Evolution. 22(2): 65-70. doi: 10.1016/j.tree.2006.09.014

LIMA, M.P., SANTOS, C.E.B., RIBEIRO, F.V., CAMPOS, K.S.C., \& MENDONÇA, J.K.S. 2009. Environmental problems at the of Munim river drainage basin at the town of Chapadinha - MA. Sociedade \& Natureza. 1(3): 421-429.

LUCINDA, P.H.F., FREITAS, I.S., SOARES, A.B., MARQUES, E.E., AGOSTINHO, C.S. \& OLIVEIRA, R.J. 2007. Fish, Lajeado Reservoir rio Tocantins drainage, State of Tocantins, Brazil. Check List. 3 (2): 70-83. doi: $10.15560 / 3.2 .70$

LYNCH, A.J., ELLIOTT, V., PHANG, S.C., CLAUSSEN, J.E., HARRISON, I., MURCHIE, K.J., STEEL, E.A. \& STOKES, G.L. 2020 Inland fish and fisheries integral to achieving the Sustainable Development Goals. Nat. Sustain. 3: 579-587. doi: 10.1038/s41893-020-0517-6

MALABARBA, L.R. \& MALABARBA, M.C. 2020 Phylogeny and Classification of Neotropical Fish. Pp. 1-19. In: BALDISSEROTTO B., URBINATI, E.C., CYRINO J.E.P. (eds.) Biology and Physiology of Freshwater Neotropical Fish. Academic Press, New York, NY, USA.

MATAVELLI, R., CAMPOS, A.M., VALE, J., PIORSKI, N.M. \& POMPEU, P.S. 2015. Ichthyofauna sampled with tadpoles in Northeastern Maranhão State, Brazil. Check List. 11(1): 1550. doi: 10.15560/11.1.1550

MOYLE, P.B. \& LIGHT, T. 1996 Biological invasions of fresh water: empirical rules and assembly theory. Biol. Conserv. 78: 149-161. doi: 10.1016/00063207(96)00024-9 
MYERS, N., MITTERMEIER, R.A., MITTERMEIER, C.G., DA FONSECA, G.A.B. \& KENT, J. 2000. Biodiversity hotspots for conservation priorities. Nature. 403: 853-858. doi: 10.1038/35002501

NASCIMENTO, M.H.S.,ALMEIDA, M.S., VEIRA, M.N.S., LIMEIRAFILHO, D., LIMA, R.C., BARROS, M.C. \& FRAGA, E.C. 2016. DNA barcoding reveals high levels of genetic diversity in the fishes of the Itapecuru Basin in Maranhão, Brazil. Genet. Mol. Res. 15(3): gmr.15038476. doi: 10.4238/gmr.15038476

NOGUEIRA, C., BUCKUP, P.A., MENEZES, N.A., OYAKAWA, O.T., KASECKER, T.P., RAMOS NETO, M.B. \& DA SILVA, M.C. 2010. Restricted-Range Fishes and the Conservation of Brazilian Freshwaters. PLoS One. 5(6): e11390. doi: 10.1371/journal.pone.0011390

NUNES, J.L.S., COSTA, M.S., RIBEIRO, M.F.R., COSTA, M.S. \& MENDES, M.B.P. 2019 Length-weight relationship for freshwater fish species from Brazilian Cerrado. J. Appl. Ichthyol. 35: 1-3. doi: 10.1111/jai.13889

OLDEN, J., KENNARD, M. \& LEPRIEUR, F. 2010. Conservation biogeography of freshwater fishes: recent progress and future challenges. Divers. Distrib. 16(3): 496-513. doi: 10.1111/j.1472-4642.2010.00655.x

OLIVEIRA-SILVA, L., RAMOS, T.P.A., CARVALHO-ROCHA, Y.G.P., VIANA, K.M.P., AVELLAR, R. C. \& RAMOS, R. T.C. 2018. Ichthyofauna of the Mamanguape river basin, Northeastern, Brazil. Biota Neotropical. 18(3): E20170452. doi: 10.1590/1676-0611-bn-2017-0452.7

OLSON, D. M., DINERSTEIN, E., POWELL, G.V.N. \& WIKRAMANAYAKE, E.D. 2002. Conservation Biology for the Biodiversity Crisis. Conserv. Biol. 16(1): 1-3. doi: 10.1046/j.1523-1739.2002.01612.x

PAIVA, M.P. 1978. A ictiofauna das grandes represas brasileiras. Revista Dae, 116: $49-57$.

PIMM, S.L., JENKINS, C.N., ABELL, R., BROOKS, T.M., GITTLEMAN, J.L., JOPPA, L.N., RAVEN, P.H., ROBERTS, C.M. \& SEXTON, J.O. 2014 The biodiversity of species and their rates of extinction, distribution, and protection. Science. 344(6187):1246752 doi: 10.1126/science.1246752

PELICICE, F.M., AZEVEDO-SANTOS, V.M., VITULE, J.R.S., ORSI, M.L., LIMA, D.P., JUNIOR MAGALHÃES, A.L.B., POMPEU, P.S., PETRERE, M.JR. \& AGOSTINHO, A.A. 2017. Neotropical freshwater fishes imperilled by unsustainable policies. Fish Fish. 10: 1-15. doi: 10.1111/faf.12228

PELICICE, F.M., AZEVEDO-SANTOS, V.M., ESGUÍCERO, A.L.H., AGOSTINHO, A.A. \& ARCIFA, M. 2018. Fish diversity in the cascade of reservoirs along the Paranapanema River, southeast Brazil. Neotrop. Ichthyol. 16(2):e170150. doi: 10.1590/1982-0224-20170150

PIORSKI, N.M. 2010. Diversidade genética das espécies de Hoplias malabaricus (Bloch, 1794) e Prochilodus macustris Steindachner, 1907 no Nordeste do Brasil. Tese de Doutorado, Universidade Federal De São Carlos, São Carlos, Brazil.

PIORSKI, N.M., FERREIRA, B.R.A., GUIMARÃES, E.C., OTTONI, F.P., NUNES, J.L.S. \& BRITO, P.S. 2017. Peixes Do Parque Nacional Dos Lençóis Maranhenses. Edufma, São Luís, Brasil.

QUINN, G. \& KEOUGH, M. 2002. Experimental Design and Data Analysis for Biologists. Cambridge Univisty Press, UK.

R Core Team.2020. R: A Language and Environment for Statistical Computing, Vienna, Austria. Available at: https://www.R-project.org/.
RAMOS, T.P.A., RAMOS, R.T.C. \& RAMOS, S.A.Q.A. 2014. Ichthyofauna of the Parnaíba river basin, northeastern Brazil. Biota Neotropica. 14(1): 1-8. doi: $10.1590 / \mathrm{S} 1676-06020140039$

REIS, R. E., KULLANDER, S. O. \& FERRARIS, C. J. JR. 2016. Fish Biodiversity and Conservation in South America. J. Fish Biol. 89(1), 12-47. doi: $10.1111 / \mathrm{jfb} .13016$

REI, S.R.E., KULLANDER, S.O. \& FERRARIS, C.J.JR. 2003. Check list of the freshwater Fishes of South and Central America. Edipucrs, Porto Alegre, Brazil.

RIBEIRO, M.F.R., PIORSKI, N.M., ALMEIDA, Z.S. \& NUNES, J.L.S. 2014 Fish aggregating known as moita, an artisanal fishing technique performed in the Munim River, State of Maranhão, Brazil. Bolet Bol Inst Pesca. 40(4): $677-82$.

RIBEIRO, F. V., GONÇALVES, L. D.P., FURTADO, M. S. \& FEITOSA, A. C. 2006. Degradação do solo no médio curso do rio Munim, município de Chapadinha- MA. In: VI Simpósio Nacional de Geomorfologia: Geomorfologia Tropical e Subtropical: processos, métodos e técnicas. Goiânia, 6-10 September 2006.

RICO-SÁNCHEZ, A.E, SUNDERMANNBC, A., LÓPEZ-LÓPEZ, E., TORRES-OLVERAD, M.T., MUELLERBC, S.A. \& HAUBROCK, P.J. 2020. Biological diversity in protected areas: Not yet known but already threatened. Glob. Ecol. Conserv. 22: e01006. doi: 10.1016/j.gecco.2020. e01006

SILVA, A.L.G., MARTINS, F. SANTOS, R. \& NUNES, J.L.S. 2008. Conservação da Reserva da Itamacaoca de Chapadinha/MA. Pp. 97-104. In: Selbach J.F., Leite J.R.S.A. (eds.) Meio Ambiente no Baixo Parnaíba: Olhos no mundo, pés na região. EDUFMA, São Luís, Brazil

SINGH, J.S. 2002. The Biodiversity Crisis: A Multifaceted Review. Curr. Sci. 82: 638-647.

SOARES, E.C. 2013. Peixes do Mearim. Instituto Geia, São Luis, Brazil.

STERNBERG, D. \& KENNARD, M.J. 2013. Environmental, spatial and phylogenetic determinants of fish life-history traits and functional composition of Australian rivers. Freshw. Biol. 58:1767 - 1778.

WHEELER, Q.D. 2008. Introductory: Toward The New Taxonomy. Pp: 1-17. In: The New Taxonomy (Wheeler Q.D,) (ed). Crc Press, New York, USA.

WILSON, E.O. 1985. The biological diversity crisis: A challenge to science. Issues Sci. Technol. Librariansh. 2(1): 20-29.

WILSON, E.O. 1999. The diversity of Life. W. W. Norton Company, New York, USA. 